\title{
Twenty-first Annual Exhibition of the Physical and Optical Societies.
}

THE twenty-first annual exhibition of the Physical and Optical Societies was opened by Sir Arthur Eddington, president of the Physical Society, on Tuesday, Jan. 6. Sir Arthur commented on the growth of the exhibition since its inception in 1905, and spoke of the mutual debt of the scientific worker and the instrument maker, saying that progress is making them more and more interdependent. All types of apparatus for physical and optical work could be seen at the exhibition, and everyone should find something of particular interest to himself. Sir Frank Smith proposed a vote of thanks, and this was seconded by Mr. H. T. Tizard, Rector of the Imperial College, where the exhibition was housed.

Electricity has steadily and rapidly taken its place at the foundations of physical science, and one has only to imagine the great reduction which would be effected on removing all electrical instruments to realise the truth of this fact. The task of making a selection of interesting items for this article would then become decidedly simplified. An interesting feature of this year's exhibition was the wide use made of photoelectric cells. Several different kinds were on view, and one of copper oxide on copper, shown by the Westinghouse Brake and Saxby Signal Co., Ltd., operating a relay, merits special comment. The Mullard Wireless Service Co., Ltd., was using a photoelectric cell to count the number of visitors to its stand, a beam of light being interrupted by each person as he approached. The exhibits of the Gramophone Co., Ltd. (H.M.V.), Research Laboratories included a demonstration of the sensitivity of its own cell with a commercial potassium cell. The former is of crsium and of the same type as used in the television apparatus ; unlike the copper oxide cell, it is most sensitive to red light. An interesting method of measuring the sensitivity of a photoelectric' cell by using it to control the output of a 'thyratron' was demonstrated by the British Thomson-Houston Co., Ltd. The current through the valve was used to drive a direct-current motor the speed of which depended on the light falling on the cell, and a loud-speaker emitted a note of a frequency dependent on the speed of the motor. A photoelectric outfit shown by Messrs. Bellingham and Stanley, Ltd., is worthy of mention. It is suitable for the photometry of light sources or general spectrometric investigations. Provision is made for the variation of the voltage on the cell as well as that on the electrometer plates, and particular care is taken to guard against the interference of external electrical disturbances.

The Research Section of the exhibition has always attracted a great deal of well-deserved attention, and has expanded considerably since it came into being only a few years ago. There is little chance here of being called upon to admire an imposing box with knobs and other protuberances which the writer personally suspects of being either empty or filled with unwanted spare parts. Perhaps a hint to exhibitors may not be out of place here. Let all apparatus be uncovered on these occasions, even if protection is necessary in general use. The physicist loves to see the wheels go round. To return to the subject: undoubtedly the most popular item in this section was the demonstration of television arranged by the Gramophone Co., Ltd. (H.M.V.), Research Laboratories. During the whole exhibition a crowd was waiting to see what further progress had been made in making the Arabian Nights become fact. The definition of the image is good and the colour is also attractive. Cinematograph pictures were scanned at the transmitter in five sections of thirty lines each, a lens drum being used to traverse a succession of images over five scanning apertures, and the received image was thrown on to a screen about two feet square. The picture was built up of 150 scanning lines and was composed of 15,000 picture elements. The frequency needed to give such detail, scanning at 12 times a second, is 23,000 cycles. Among the fifteen demonstrations arranged in this section by the National Physical Laboratory, selecting any one for special comment is not easy. The Radio Research Board was using a resonant wavemeter circuit to show the existence of side-bands when a radio-frequency oscillation is modulated by an audio-frequency oscillation. Messrs. L. F. G. Simmons and H. C. H. Townend were demonstrating an interesting method of examining the air-flow past models by heating the air in horizontal layers with hot wires. The changes in refractive index of the air were used to trace the shape of the flow lines round the body in a shadowgraph. Apparatus shown by Messrs. F. H. Schofield and J. A. Hall was some of that used in establishing the absolute scale of temperature from $-183^{\circ} \mathrm{C}$. upwards, and included a platinum resistance thermometer, platinum thermocouple, and optical pyrometer. $\mathrm{Dr}$. Ezer Griffiths had on view a multiple thermo-element type hygrometer for distant reading which can be used in a ship's hold. An apparatus for measuring the flow through flues was demonstrated by the Gas, Light, and Coke Co. (Research and Training Section). The temperature at various points is observed and from the temperature-gradient the rate of flow deduced. A surprising fact is that the temperature across a section is far from uniform. Since the flow of gases is turbulent, this is rather unexpected and opens the field for further work on the subject. The Rothamsted Experimental Station showed a bridge for studying the water in soils and the nature of the association of the two, by passing an alternating current and noting the phase angle between this and the electromotive force. Not all the water is available for plant life, and vegetation may wither in quite damp soil if the water present is combined with the soil. An exhibit illustrating phase-change in tuned circuits, due to the British Thomson-Houston Co., Ltd., is worthy of note. A fixed primary coil formed the inductance of an oscillating circuit, and a swinging secondary coil was arranged so that the coupling between the two coils was periodically varied. As the secondary vibrated the circuits passed through the resonance point and there were alternating attracting and repulsing forces due to sudden phase-change. The position of the pendulum at which the phase jump occurred was different for the two directions of movement, and this caused a series of impulses which maintained the motion.

The Trade Section of the exhibition had many examples of good workmanship, and the optical instruments - especially epidiascopes shown by Messrs. Carl Zeiss (London), Ltd., and Messrs. W. Edwards and Co.-may be mentioned in particular. Messrs. Edwards also demonstrated several kinds of vacuum pumps, one of which-the 'Hypervac' rotary oil pump-will produce a pressure so low as $0.00005 \mathrm{~mm}$. The Cambridge Instrument Co., Ltd., exhibited many new instruments, those for use in geophysical surveying being of special interest, and described in Mr. Lancaster-Jones's discourse on Jan. 7. The eight pages in the programme describing these instruments are worth studying. The Leakey-Harper drawing machine lent by Sir Arthur Keith may also be mentioned. In addition to the instruments specified in the programme, Messrs. Adam Hilger,

No. 3194, Vox. 127] 
Ltd., showed a Fabry-Perot etalon with variable separation. This is a beautifully made apparatus. The plates are supported on invar in order to reduce temperature effects to a minimum during long exposures. The instrument is suitable for measuring wave-lengths in terms of a standard and observing fine structure in the longer wave-lengths of the spectrum. The Munsell Colour Books, intended to form the basis of a system of colour specification, and $\mathrm{X}$-ray gratings prepared in the laboratories of Prof. M. Siegbahn, were on view, as well as an all-metal quartz spectrograph. Of special interest to teachers was the astronomical model designed by Mr. W. Wilson and exhibited by Messrs. A. Gallenkamp and Co., Ltd., which demonstrates the motion of the earth, moon, and sun. Each separate movement can be shown alone and the bodies can be made to perform hypothetical motions. This should prove particularly valuable for educational purposes, since the reasons for day and night and seasons will be understood at once on seeing movements which do not produce them. Both the M.O. Valve Co., Ltd., and the Mullard Wireless Service Co., Ltd., had a large selection of transmitting, rectifying, and modulating thermionic valves. The M.O. Valve Co., Ltd., was demonstrating an assembly operation in which the supports for the inside of a valve were bent to the required shape by one movement of a handle.

In the section for apprentices and learners started last year some good workmanship was on view. In Class A (Craftsmanship), first prizes were awarded to T. E. Bayley (under eighteen years), of Marconi's Wireless Telegraph Co., Ltd., for a signalling relay, and to H. G. Freshwater, of Messrs. H. Tinsley and Co., for a vibrating galvanometer suspension. This competitor also obtained the Finsbury prize. In Class B (Draughtsmanship), first prizes were taken by W. G. Hill (under eighteen years), of Messrs. H. Hughes and Son, Ltd., for a periscope wind gauge bearing plate, and by E. G. Mansfield, of the General Electric Co., Ltd. (Research Laboratories), for a controller for a motor operated rheostat. It is to be hoped that this section will continue to grow as time goes on, since the importance of good instruments to the physicist cannot be over-estimated.

Two discourses were delivered in the large physics lecture theatre, both extremely interesting and very well attended. The first, by Mr. E. LancasterJones, was entitled "Searching for Minerals with Scientific Instruments". Mr. Lancaster-Jones described the four methods used in locating salt deposits, oil, and other minerals, and mentioned the fact that all the instruments which he had in the room werewith only one exception-of British manufacture. The four types of instrument used are : gravitational, magnetic, seismic, and electrical. In the first of these methods the instrument measures the value of gravity at different points, and from the variation from normal a mound of denser material than the surrounding earth can be easily located. Salt is generally discovered in this way, and its discovery is important, since oil usually occurs with it. In the second method the horizontal intensity of the earth's mag. netic field is measured, and the existence of magnetic veins disclosed. The third method is very interesting. An explosion is made at one point, and three sound waves travel to the recording instrument: one through the air, one just beneath the ground, and one penetrates the surface as far as a layer of material of different density below ground and then travels along the top of this layer. The velocities of sound in air and in the two substances are known, the times of arrival of the waves are recorded by the seismograph and, with the distance of the explosion, all the necessary data for finding the position of the mineral deposit are available. The fourth method consists in tracing out lines of equal electrical potential between two electrodes across which an alternating current is passing. These lines have a curved shape when copper or similar material exists below the surface. The lecture was illustrated by experiments and slides.

On Thursday, when the exhibition was open free to the general public, Sir Gilbert Walker gave an interesting account of "Physics in Sport". Sir Gilbert said that the tendency to separate applied mathematics from the happenings of everyday life was to be deplored, and then proceeded to make his audience agree with this statement by giving an explanation of the behaviour of balls. He went on to give some idea of the principles involved in such sports as curling, spear-throwing, and boomerangthrowing. The discourse was illustrated by a selection of slides and experiments, the strange behaviour of a coin when rolled on a billiard table causing much amusement.

Many hours can be spent at an exhibition of this kind and another visit will still reveal something fresh. The secretary is to be congratulated on the success of his organisation. The amount of time and thought devoted to making a success of these occasions is scarcely ever realised by those who enjoy its fruits.
E. M. Collins.

\section{Annual Meeting of the Science Masters' Association.}

THE thirty-first annual meeting of the Science Masters' Association was held at the University, Edgbaston, Birmingham, on Jan. 6-9. The meeting opened during one of the worst fogs on record, but in spite of this more than two hundred members and guests, including the Lord Mayor (Alderman Saunders), were able to find their way to the dinner and the presidential address. Altogether more than four hundred members attended the meetings. The University buildings are admirably adapted for the purposes of such a conference, and the staffs of the various departments of pure and applied science arranged a very fine series of demonstrations in the laboratories. The exhibition of apparatus and books was held in the spacious drawing office, which is an ideal room for the purpose.

The presidential address was given by Sir Charles Grant Robertson, Vice-Chancellor of the University, who referred to the fact that boys and girls and the young university graduate and teacher of to-day fail to realise the immense revolution that has taken place in the world of thought and education during the last fifty years. In that period there has been a scientific renaissance comparable in the quality and scope of its range to the humanistic renaissance of the fifteenth and sixteenth centuries. The result is that the monopoly of the classical humanists has been overthrown and smashed to pieces, resulting in the admission of other subjects into the school curriculum. Sir Charles went on to say that, "confronted with the modern curriculum, Huxley would have in sisted that the number of subjects taught is far too large and must be drastically reduced, and for the simple reason that the identification of education with the acquisition of information is an indictable mis. demeanour". He (Sir Charles) was profoundly impressed with the ability of undergraduates in the faculties of science, but he often found that they were lacking in general culture. Personally he would like to see the training in science continued for every boy 